\title{
Article
}

\section{Analysis of Heavy Metal Distribution in Regional Sediments Batang Ayumi River Flow}

\section{Article Info}

Article history :

Received July 23, 2020

Revised September 12, 2020

Accepted September 27, 2020

Published September 30, 2020

\section{Keywords :}

Metal $\mathrm{Cu}, \mathrm{Hg}, \mathrm{Pb}, \mathrm{AAS}$, Batang Ayumi River

\section{Fatma Suryani Harahap, Adi Syaputra}

Department of Chemical Education, Universitas Muhammadiyah Tapanuli Selatan, Indonesia

\begin{abstract}
The presence of heavy metals in waters can be sourced from household activities, agricultural waste and industrial waste. Some heavy metals are toxic, such as $\mathrm{Cu}, \mathrm{Hg}$, and $\mathrm{Pb}$, which can accumulate in aquatic sediments. Sediment contaminated with heavy metals will harm the organisms that live in it. This study aims to identify the concentration of $\mathrm{Cu}, \mathrm{Hg}$, and $\mathrm{Pb}$ heavy metals in the sediments of the Batang Ayumi River. This study used a descriptive exploratory method by conducting a survey first. Determination of the sampling location using purposive sampling method at four designated stations. This study used an Atomic Absorption Spectrophotometer. Data analysis was performed by comparing the test result data with quality stones issued by the IADC / CEDA. The test results showed the value of the metal concentration of $\mathrm{Cu}$ $(<0,006 \mathrm{ppm}), \mathrm{Hg}(<0,0011 \mathrm{ppm})$ and $\mathrm{Pb}(<0,003 \mathrm{ppm})$. The concentration shows that the content of heavy metals $\mathrm{Hg}, \mathrm{Pb}$ and $\mathrm{Cu}$ in the sediment is very low below the AAS detection limit, so the substances in the sediment are not too dangerous for the environment. The contribution of this research is expected to provide information about the quality of the Ayumi Batang River and can be used as a consideration in formulating policies in controlling pollution that occurs in the river.
\end{abstract}

This is an open acces article under the $\underline{C C-B Y}$ license.

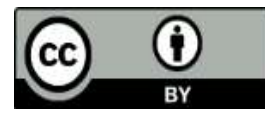

This is an open access article distributed under the Creative Commons 4.0 Attribution License, which permits unrestricted use, distribution, and reproduction in any medium, provided the original work is properly cited. (C2020 by author.

\section{Corresponding Author :}

Fatma Suryani Harahap

Department of Chemical Education, Universitas Muhammadiyah Tapanuli Selatan, Indonesia

Email : fatma.suryani@um-tapsel.ac.id

\section{Introduction}

Human activities along the River Basin (DAS) produce pollutants that are harmful to the environment that follows the river flow. The higher the activity of the population along the watershed the higher the possibility of large-scale pollutants. Batang Ayumi River which crosses 
through Padangsidimpuan City which is the pride and memories of the city residents in the past, now the condition is not only narrowed by the mushrooming of the construction of buildings on the banks / banks of the river also the conditions have become increasingly shallow due to sedimentation due to piles of rubbish.

The results of previous studies in the Batang Ayumi River [1] mentioned an increase in the concentration of $\mathrm{Cu}$ metal at two stations around $\pm 0.05 \mathrm{mg} / \mathrm{L}$. The presence of heavy metals in waters can be sourced from mining, household, agricultural waste and industrial wastes. Some heavy metals are toxic such as $\mathrm{Cu}, \mathrm{Hg}, \mathrm{Cr}, \mathrm{Pb}$ and $\mathrm{Ni}$ can accumulate in aquatic sediments.

Heavy metals in the water column eventually fall to the bottom of the waters and eventually settle in the sediment. [2] explained that the presence of heavy metals is often associated with suspended particles in the water and sedimentary columns. When compared, the presence of heavy metals in sediments is more stable than in the water column. Sediments that are contaminated with heavy metals will endanger the organisms that live in them. Sediments are easily suspended because of the movement of the water mass which dissolves the metal they contain back into the water so that the sediment becomes a potential source of pollutants in a certain time scale.

Heavy metals in waters, directly or indirectly, endanger the life of organisms and human health. [3]. This relates to the properties of heavy metals that are difficult to degrade, so they are easy to accumulate in the environment of the breakdown and their presence is naturally difficult to decompose. Information about heavy metals in sediments in waters is needed. Ayumi Trunk is one of the waters that have little information related to heavy metals. Therefore it is necessary to carry out further research to what extent the distribution or distribution of heavy metals $\mathrm{Cu}$ and other toxic heavy metals such as $\mathrm{Hg}, \mathrm{Cr}, \mathrm{Pb}$ and $\mathrm{Ni}$ pollute the Batang Ayumi River. This study aims to identify the concentration of $\mathrm{Cu}, \mathrm{Hg}$ and $\mathrm{Pb}$ heavy metals in sediments in the Batang Ayumi River. The novelty of this research is the recentness of accurate data information regarding the quality of the Batang Ayumi river in terms of the distribution of heavy metals.

\section{Experimental Section}

\section{Time and Location of Research}

This research was carried out for four months starting in January-April 2020. Sampling of this study was carried out at four sampling stations on the Batang Ayumi river that flows through Padangsidimpuan City. Testing of heavy metal content in sediments was carried out at the Medan Industrial Research and Standardization Testing Laboratory (BARISTAND).

\section{Tools and Materials}

The tools used in this study were a coolbox, oven, PE plastic, Atomic Absorption Spectrophotometer (AAS), a digestion device. The materials used in this research were river soil samples from four sampling stations, $\mathrm{HNO}_{3}(\mathrm{p})$, aquadest, metal standard solutions $(\mathrm{Cu}, \mathrm{Hg}$ and $\mathrm{Pb})$, $\mathrm{H}_{2} \mathrm{SO}_{4}(\mathrm{p})$.

\section{Sampling Method}

This study uses a descriptive exploratory method by conducting a survey in advance. Determination of where to take samples using "Purposive Random Sampling". at the four stations specified. The four research stations can be seen in the following station descriptions:

\section{a. Station 1}

This station is in the village of Pintu Langit Jae, Padangsidimpuan Angkola Julu District. The village is still very beautiful and the population is not much and is a control station.

b. Station 2

This station is located in Padangsidimpuan Batunadua District. Batu Bola Village.

\section{c. Station 3}

http://www.eksakta.ppj.unp.ac.id/index.php/eksakta 
This station is located in South Padangsidimpuan District. In this area various community activities are found, such as bathing, washing, and using latrines.

d. Station 4

This station is located in Sihitang Sub-District, Padangsidimpuan Tenggara District. In this area various community activities are found, such as bathing, washing, toilet and bypassing the flow of waste from hospitals and factories and is downstream of the Batang Ayumi river that passes through Padangsidimpuan City.

Sediment samples were taken at a depth of $10-15 \mathrm{~cm}$ and $30-50 \mathrm{~cm}$ from the surface of $100-200 \mathrm{~g}$ from each station, then put together into a composite sample. Furthermore sample preparation until sample testing is carried out at BARISTAND.

\section{Sediment Sample Preparation}

Sediment sample preparation was started by drying in an oven at $1050 \mathrm{C}$ for 3 hours. The dry sediment obtained is ground until smooth. The resulting sediment powder was weighed 1 gram and put into a beaker, then added HNO3 and H2SO4. Furthermore, $20 \mathrm{ml}$ of HNO3 / HCL mixture was added and digested for 3 hours at $120 \mathrm{oC}$. The results of this destruction are filtered and the filtrate is collected in a $50 \mathrm{ml}$ volumetric flask and diluted with distilled water until the limit mark. The filtrate is then measured by AAS [4].

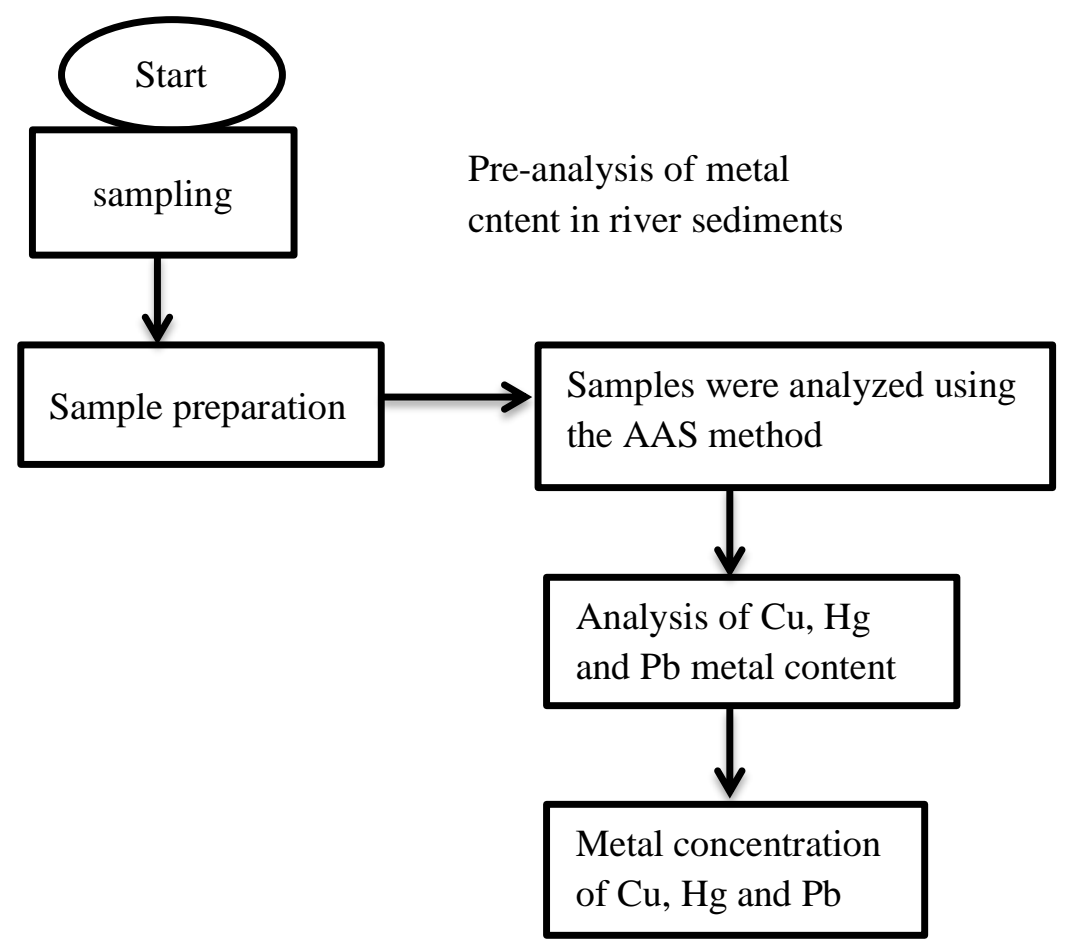

\section{Data Analysis}

Figure 1. Research flow chart

The concentrations of heavy metals $\mathrm{Cu}, \mathrm{Hg}$ and $\mathrm{Pb}$ obtained from the research results will then be compared with the concentration of quality standards in sediments based on the Dutch quality standards issued by IADC / CEDA (1997). If the contaminant concentration in the sediment has a 
value that is less than the target level value, then the substance present in the sediment is not too dangerous for the environment. If the contaminant concentration in the sediment is in the range of values between the limit level and the test level, it is categorized as lightly polluted. If the contaminant concentration in the sediment is in the range of values between the test level and the intervention level, it is categorized as moderately polluted. If the contaminant concentration is at a value greater than the hazard level quality standard, sediment removal must be carried out immediately.

\section{Result and Discussion}

\section{Heavy Metal Content in River Sediments}

Heavy metals are a term commonly used for groups of metals and metalloids with densities greater than $5 \mathrm{~g} / \mathrm{cm} 3$, especially in elements such as $\mathrm{Cd}, \mathrm{Cr}, \mathrm{Cu}, \mathrm{Hg}, \mathrm{Ni}, \mathrm{Pb}$ and $\mathrm{Zn}$. Unlike ordinary metals, heavy metals usually have special effects on living things. Heavy metals can be toxic substances that will poison the bodies of living things, but some types of metal are still needed by living things, even in small amounts. The presence of heavy metals in waters can come from various sources, including mining, household, agricultural waste and industrial waste [5]. Heavy metals naturally have low concentrations in waters. High and low concentrations of heavy metals are caused by the amount of heavy metal waste input into the waters. The greater the waste that enters into a waters, the greater the concentration of heavy metals in the waters. Besides the season also affects the concentration, where in the rainy season heavy metal concentrations tend to be lower because it is diluted by rain water. Heavy metals that enter the waters will experience sedimentation, dilution and dispersion, then absorbed by organisms that live in the waters. Precipitation of heavy metals occurs due to the presence of carbonate, hydroxyl and chloride anions [6].

Table 1. Results of measurements of heavy metals in sediments

\begin{tabular}{|c|c|c|c|}
\hline \multicolumn{4}{|c|}{ Metal Concentration (mg/kg) } \\
\hline & Copper $(\mathrm{Cu})$ & Mercury (Hg) & Lead $(\mathrm{Pb})$ \\
\hline Station 1 & $<0,006$ & $<0,0011$ & $<0,003$ \\
\hline Station 2 & $<0,006$ & $<0,0011$ & $<0,003$ \\
\hline Station 3 & $<0,006$ & $<0,0011$ & $<0,003$ \\
\hline Station 4 & $<0,006$ & $<0,0011$ & $<0,003$ \\
\hline
\end{tabular}

Basically, mercury / mercury $(\mathrm{Hg})$ is a metal element that is very important in technology in today's modern age. Physical and chemical form is very advantageous because it is the only metal that is liquid at room temperature $\left(25^{\circ} \mathrm{C}\right)$, the lowest freezing point $\left(-39^{\circ} \mathrm{C}\right)$, has a tendency to evaporate more, easily mixed with other metals into metals mixture (amalgam / alloy), can also flow electric current as a conductor both at high electric current and low electric current [7]. Mercury originates from volcanic activity, seepage of ground water that passes through areas containing mercury. Concentration increases after humans use mercury as industrial material [8]. In addition to natural influences, the presence of mercury in the environment can come from a variety of human activities that produce mercury waste such as gold mining waste, agriculture, metal mixing, catalysts in mining, dentistry, electrical equipment, medicines and laboratory uses which are then largely discarded to the surrounding environment [9]. Mercury $(\mathrm{Hg})$ contained in waste (waste) in public waters is changed by the activity of microorganisms into a component of methyl-mercury (Me-Hg) which has toxic properties and strong binding capacity in addition to high solubility, especially in the body of aquatic animals. This results in the accumulation of mercury both through 
bioaccumulation and biomagnification processes, namely through the food chain in the body tissues of aquatic animals, so that mercury levels can reach dangerous levels for both aquatic animal life and human health that consume animal catches these aquatic animals [10]. The results of measuring $\mathrm{Hg}$ levels in the sediments of the Batang Ayumi river show that the content of heavy metal $\mathrm{Hg}$ in the sediments is still very low, the data shows that the detection of $\mathrm{Hg}$ metal concentrations is still below the AAS detection limit.

Leads containing lead (gasoline) make a significant contribution to the presence of lead in water. Lead content and toxicity in water are influenced by hardness, $\mathrm{pH}$, alkalinity, and oxygen level [11]. In animals and humans lead can enter the body through food and drink consumed as well as through breathing and penetration of the skin. In the human body, lead can inhibit the activity of enzymes involved in the formation of hemoglobin which can cause anemia. Symptoms resulting from lead metal poisoning are lack of appetite, convulsions, lethargy and weakness, vomiting and dizziness. Lead can also attack the nervous system, digestive tract and depression [12].

Table 2. Quality standards of heavy metals in sediments

\begin{tabular}{lllllll}
\hline $\begin{array}{l}\text { Meavy } \\
\text { metal }\end{array}$ & Symbol & $\begin{array}{l}\text { Level } \\
\text { target }\end{array}$ & $\begin{array}{l}\text { Level } \\
\text { limit }\end{array}$ & $\begin{array}{l}\text { Level } \\
\text { test }\end{array}$ & $\begin{array}{l}\text { Level } \\
\text { intervention }\end{array}$ & $\begin{array}{l}\text { Level } \\
\text { danger }\end{array}$ \\
\hline Mercury & $\mathrm{Hg}$ & 0,3 & 0,5 & 1,6 & 10 & 15 \\
Lead & $\mathrm{Pb}$ & 85 & 530 & 530 & 530 & 1000 \\
Copper & $\mathrm{Cu}$ & 35 & 35 & 90 & 190 & 400 \\
& & & & & & \\
\hline
\end{tabular}

Source : IADC/CEDA (1997)

Information:

a. Target level. If the concentration of contaminants in the sediment has a value that is smaller than the target level value, then the substance in the sediment is not too dangerous for the environment.

b. Limit level. If the concentration of contaminants in the sediment has a maximum value that can be tolerated for human health or the ecosystem.

c. Test level. If the concentration of contaminants in the sediment is in the range of values between the limit level and the test level, then it is categorized as mild contaminated.

d. Intervention level. If the concentration of contaminants in the sediment is in the range of values between the test level and the intervention level, then it is categorized as moderately polluted.

e. Danger level. If the concentration of contaminants is at a value greater than the quality standard, the hazard level must be cleaned up immediately.

The results of research on mercury, copper and lead content in sediments compared to natural levels that exist are still below the specified lower threshold that is below 10,0000 ppm (RNO, 1981) and below 5,000 ppm EPA (1990). Mercury measurement results obtained by <0,0011 ppm when compared with the quality standards of the IADC / CEDA (1997) are still far below the limit level $(<530,0000 \mathrm{ppm})$, even far below the target level of $<85,0000 \mathrm{ppm}$. Although the results of copper measurements in the Ayumi stem river water have exceeded the threshold in accordance with government regulations, according to PP No.82 of 2001 but the results of copper measurements in sediment that is equal to $(<0,006)$ are still far below the target level $(<35,0000 \mathrm{ppm})$. The results of the measurement of lead metal which is equal to $(<0,003 \mathrm{ppm})$ are also far from the target level $(85,0000 \mathrm{ppm})$. In general the content of heavy metals $(\mathrm{Hg}, \mathrm{Pb}$ and $\mathrm{Cu})$ in sediments in the Batang 
Ayumi river can still be tolerated for human health and ecosystems. The condition of the river is still healthy and has not experienced heavy pollution. But if the community continues to dump garbage into the river, then the use of high synthetic pesticides near the waters will eventually accumulate even more heavy metals.

\section{Conclusion}

The results of research on the content of mercury, copper and lead in the sediments of the Batang Ayumi river were still far below the target level according to the quality standard stipulations of the IADC / CEDA (1997), the results of measuring the concentration of $\mathrm{Hg}$ metal were $<0,0011$ ppm while the large concentration indicated sediment. polluted, namely $<3,0000 \mathrm{ppm}$, the result of measuring the concentration of $\mathrm{Cu}$ metal is $<0,006 \mathrm{ppm}$ while the concentration that states the sediment is polluted is $<35 ., 000 \mathrm{ppm}$, the measurement results of the concentration of $\mathrm{Pb}$ metal is $<0,003 \mathrm{ppm}$ while the concentration that states the sediment is polluted is $<85,0000 \mathrm{ppm}$. Therefore, the results of heavy metal concentration measurements show that the heavy metals $(\mathrm{Hg}, \mathrm{Pb}$ and $\mathrm{Cu})$ in the sediments in the Batang Ayumi river are not too dangerous for the environment and can still be tolerated for human health and the ecosystem.

\section{Acknowledgement}

Thanks to the Ministry of Education and Culture. This research is supported by the Ministry of Education and Culture's Beginner Lecturer Research Grant in accordance with the research contract for the 2020 year Number: 18/LL1/PG/2020.

\section{References}

1. F. Harahap, "Analysis of Heavy Metals Distribution in the River Town of Hamasakis'"s Rod Padangsidimpuan. Eksakta," Eksakta, vol. 19, no. 2, pp. 50-56, 2018.

2. E. Supriyaningrum, "Fluktuasi Logam Berat Timbal dan Kadmium dalam Air dan Sedimen di Perairan Teluk Jakarta,” IPB, 2006.

3. E. J. Duruib JO, Ogwuegbe MOC, "Heavy Metal Pollution and Human biotoxic Effects," Int.J.Of Phys. Sci, vol. 2, no. 5, pp. 112-118, 2007.

4. M. Siaka, "Korelasi Antara Kedalaman Sedimen di Pelabuhan Benoa dan Konsentrasi Logam Berat $\mathrm{Pb}$ dan $\mathrm{Cu}$," J. Kim. 2, 2008.

5. H. Palar, Pencemaran dan Toksikologi Logam Berat. Jakarta: Rineka Cipta, 2008.

6. B. Barus, "Analisis Kandungan Logam Berat Kadmium (Cd) dan Merkuri (Hg) pada Air dan sedimen di Perairan Muara Sungai Banyuasin," Maspari, vol. 9, no. 1, pp. 69-76, 2017.

7. Z. Alfian, "Merkuri: Antara Manfaat dan Efek Penggunaannya Bagi Kesehatan Manusia dan Lingkungan," 2006. 1. F. Harahap, "Analysis of Heavy Metals Distribution in the River Town of Hamasakis'"s Rod Padangsidimpuan. Eksakta," Eksakta, vol. 19, no. 2, pp. 50-56, 2018.

8. S. Mulyaningsih, TR, Alfian, "Distribusi Logam Berat dalam Sedimen Daerah Aliran Sungai Ciujung Banten,” J. Tek. Reakt. Nukl, vol. 14, no. 3, pp. 157-169, 2012.

9. A. Sarjono, "Analisis kandungan Logam Berat $\mathrm{Cd}, \mathrm{Pb}$ dan $\mathrm{Hg}$ pada Air dan Sedimen di Perairan Kamal Muara," IPB, 2009.

10. Harizal, "Studi Konsentrasi Logam Berat Merkuri (Hg) Pada Kerang Hijau (Perna Viridis) Sebagai Bio Monitoring Pencemaran Di perairan Pantai Banyu Urip Kecamatan Ujung Pangkah Kabupaten Gresik," Universitas Brawijaya, 2006.

11. H. Effendi, Telaah Kualitas Air Bagi Pengolahan Sumber Daya dan Lingkungan Perairan. Yogyakarta: Kanisius, 2003. 
12. D. R, A.H, Masyamsir, Yayat, "Distribusi Kandungan Logam Berat $\mathrm{Pb}$ dan $\mathrm{Cd}$ Pada Kolom Air dan Sedimen daerah Aliran Sungai Citarum Hulu," J. Perikan. dan Kelaut., vol. 3, no. 3, pp. 175-182, 2012.

13. Aslam S, Chan MWH, Siddiqui G, Boczkaj G, Kazmi SJH, Kazmi MR. (2020). A comprehensive assessment of environmental pollution by means of heavy metal analysis for oysters' reefs at Hab River Delta, Balochistan, Pakistan. Marine pollution bulletin.153:110970.

14. Karimian S, Chamani A, Shams M. (2020). Evaluation of heavy metal pollution in the Zayandeh-Rud River as the only permanent river in the central plateau of Iran. Environmental monitoring and assessment.192(5):316.

15. Khan MHR, Liu J, Liu S, Li J, Cao L, Rahman A. (2020). Anthropogenic effect on heavy metal contents in surface sediments of the Bengal Basin river system, Bangladesh. Environmental science and pollution research international.27(16):19688-702.

16. Nguyen A, Le BVQ, Richter O. (2020). The Role of Mangroves in the Retention of Heavy Metal (Chromium): A Simulation Study in the Thi Vai River Catchment, Vietnam. International journal of environmental research and public health.17(16).

17. Nguyen BT, Nguyen VN, Truong HTT, Do DD, Nguyen TX, Nguyen DTP, et al. (2020). Assessment and source quantification of heavy metal(loid)s in surface water using multivariate analyses from the Saigon River, Vietnam. Environmental science and pollution research international.27(16):19383-97.

18. Shahmoradi B, Hajimirzaei S, Amanollahi J, Wantala K, Maleki A, Lee SM, et al. (2020). Correction to: Influence of iron mining activity on heavy metal contamination in the sediments of the Aqyazi River, Iran. Environmental monitoring and assessment.192(8):556.

19. Shahmoradi B, Hajimirzaei S, Amanollahi J, Wantalla K, Maleki A, Lee SM, et al. (2020). Influence of iron mining activity on heavy metal contamination in the sediments of the Aqyazi River, Iran. Environmental monitoring and assessment.192(8):521.

20. Singh P, Purakayastha TJ, Mitra S, Bhowmik A, Tsang DCW. (2020). River water irrigation with heavy metal load influences soil biological activities and risk factors. Journal of environmental management.270:110517.

21. Szczepaniak-Wnuk I, Gorka-Kostrubiec B, Dytlow S, Szwarczewski P, Kwapulinski P, Karasinski J. (2020). Assessment of heavy metal pollution in Vistula river (Poland) sediments by using magnetic methods. Environmental science and pollution research international.27(19):24129-44.

22. Thomas JCt, Oladeinde A, Kieran TJ, Finger JW, Jr., Bayona-Vasquez NJ, Cartee JC, et al. (2020). Co-occurrence of antibiotic, biocide, and heavy metal resistance genes in bacteria from metal and radionuclide contaminated soils at the Savannah River Site. Microbial biotechnology.13(4):1179-200.

23. Turan F, Eken M, Ozyilmaz G, Karan S, Uluca H. (2020). Heavy metal bioaccumulation, oxidative stress and genotoxicity in African catfish Clarias gariepinus from Orontes river.

24. Ucun Ozel H, Gemici BT, Gemici E, Ozel HB, Cetin M, Sevik H. (2020). Application of artificial neural networks to predict the heavy metal contamination in the Bartin River. Environmental science and pollution research international.

25. Uwah EI, Nwoke IB, Inam EJ, Udosen IE, Udosen ED. (2020). Human Health Risk Assessment of Heavy Metal Contamination in New Calabar River. Bulletin of environmental contamination and toxicology.105(2):317-24. 
26. Wu W, Qu S, Nel W, Ji J. (2020). The impact of natural weathering and mining on heavy metal accumulation in the karst areas of the Pearl River Basin, China. The Science of the total environment.734:139480.

27. Wulan DR, Marganingrum D, Yoneda M. (2020). Distribution, source identification, and assessment of heavy metal pollution in the surface and pore waters of Cipeles River, West Java, Indonesia. Environmental science and pollution research international.

28. Xiong B, Xu T, Li R, Johnson D, Ren D, Liu H, et al. (2020). Heavy metal accumulation and health risk assessment of crayfish collected from cultivated and uncultivated ponds in the Middle Reach of Yangtze River. The Science of the total environment.739:139963.

29. Yang CP, Liu Y, Shan BB, Xu J, Yu W, Sun DR, et al. (2020). Heavy metal concentrations and associated health risks in edible tissues of marine nekton from the outer Pearl River Estuary, South China Sea. Environmental science and pollution research international.

30. Yang HJ, Jeong HJ, Bong KM, Jin DR, Kang TW, Ryu HS, et al. (2020). Organic matter and heavy metal in river sediments of southwestern coastal Korea: Spatial distributions, pollution, and ecological risk assessment. Marine pollution bulletin.159:111466.

31. Yang S, Qu Y, Ma J, Liu L, Wu H, Liu Q, et al. (2020). Comparison of the concentrations, sources, and distributions of heavy metal(loid)s in agricultural soils of two provinces in the Yangtze River Delta, China. Environmental pollution.264:114688.

32. Zare Khosheghbal M, Esmaeilzadeh M, Ghazban F, Charmsazi ME. (2020). Heavy metal pollution status in surface sediments of the Khajeh Kory River, north Iran. Water science and technology : a journal of the International Association on Water Pollution Research.81(6):1148-58.

33. Zhang F, Shen C, Wang S, Jia Y. (2020). Application of the RUSLE for Determining Riverine Heavy Metal Flux in the Upper Pearl River Basin, China. Bulletin of environmental contamination and toxicology.

34. Zhang W, Liu M, Li C. (2020). Soil heavy metal contamination assessment in the Hun-Taizi River watershed, China. Scientific reports.10(1):8730.

35. Zhao X, Huang J, Zhu X, Chai J, Ji X. (2020). Ecological Effects of Heavy Metal Pollution on Soil Microbial Community Structure and Diversity on Both Sides of a River around a Mining Area. International journal of environmental research and public health.17(16). 